\title{
LA OCUPACIÓN DE JERUSALÉN ORIENTAL Y DE PALESTINA EN EL BARRIO DE LOS CRISTIANOS, DE NABIL JURI
}

\author{
Clara Ma Thomas de Antonio \\ Universidad de Sevilla
}

\begin{abstract}
Resumen: Este artículo analiza la historia de la ocupación de Jerusalén Oriental y de toda la tierra de Palestina a través de los recuerdos de la viuda de un héroe de la resistencia, tal como lo relata el escritor palestino Nabil Juri en su novela El Barrio de los Cristianos.
\end{abstract}

Palabras clave: Palestina, novela palestina, Nabil Juri, resistencia palestina, ocupación israelí de Palestina.

Abstract: This paper analyses the history of the occupation of East Jerusalem and the whole of Palestinian land through the remembrance of the widow of an resistance's hero, as related by the palestinian writer Nabil Juri in his novel The Christian Quarter.

Keywords: Palestine, Palestinian Novel, Nabil Juri, Palestinian Resistance, Israeli Occupation of Palestine.

El escritor palestino Nabil Juri nació en Jerusalén en 1934, pero a los 20 años tuvo que exiliarse al Líbano, donde trabajó en los medios de comunicación y en diversas revistas. Años más tarde, en 1974, también tendrá que marchar aún más lejos de Palestina, a París, donde fundó la revista al-Mustaqbal, trabajó para el diario libanés al-Nahar, y siguió dedicado a escribir...

Además de su actividad periodística, recogida en parte en esos Artículos airados que escribía para al-Mustaqbal, publicó más de una docena de novelas y colecciones de relatos. Entre sus obras destacan Las lámparas azules (1957), su primera novela; Los dos exilios (1992), dedicada a sus dos forzados alejamientos de la patria; Las hojas de otoño (1994), una especie de autobiografía; y la que ahora nos ocupa, El Barrio de los Cristianos (Harat al-Nasara)', publicada en 1968 como fruto de su experiencia directa de la ocupación de Jerusalén Oriental y del resto de la Palestina histórica en la llamada Guerra de los Seis Días o Guerra de Hazirán, como él mismo dice en el prólogo de la novela:

1 Este trabajo se basa en la versión española realizada por Said Alami y titulada El barrio cristiano. Madrid, CantArabia, 1996. 
El diez de junio de 1967 yo estaba en Jerusalén. La batalla había terminado, y el ejército de Israel ocupaba la ciudad.

Los cadáveres llenaban la calle, sin que se encontrase quien cavara una tumba o quien echara sobre ellos un puñado de tierra.

Mis sentimientos, los sentimientos de todos, eran una mezcla de asco, humillación, rabia... y derrota (p. 5).

Juri no podía creer que su ciudad y el resto de Palestina hubieran caído con tanta rapidez:

¿Cómo era posible que, después de todos estos años fortificándonos, de estar preparados, Israel conquistara Jerusalén y grandes extensiones de la patria árabe en una batalla que más bien había sido un paseo? (p. 6).

Esta sensación de derrota, que tanto afectó a todo el mundo árabe, les hizo pensar a muchos que no había otra salida que rendirse, renunciar a su patria y limitarse a pedir un Estado independiente en lo que aún les quedaba. Pero el estallido de una nueva revolución, en que la resistencia palestina reanudó su lucha contra Israel, les hizo recobrar la dignidad y la esperanza. Y de esas vivencias personales surgió su novela El Barrio de los Cristianos.

Para narrar estos dramáticos hechos, Nabil Juri se centra en la historia de su amigo Yúsef Ráshed, cuya muerte había presenciado con sus propios ojos al final de la batalla por Jerusalén, el 8 de junio de 1967. Y para ello se mete en la piel de su viuda, Salma, que, sentada ante la fotografía enlutada de su marido muerto y en una narración no lineal, va recordando sus vidas y la historia de la lucha por Palestina.

Yúsef y Salma eran cristianos y vivían en el Barrio Cristiano en la Ciudad Vieja de la Jerusalén oriental, la Jerusalén árabe. Yúsef había nacido en plena guerra mundial y había muerto en su ciudad con algo más de 50 años, en los que había participado en todos los enfrentamientos palestinos contra los judíos. Y de ese medio siglo, Salma había compartido con él más de la mitad. Por eso podía recordar multitud de detalles sobre las batallas palestinas más relevantes contra la ocupación israelí, puesta en marcha desde 1917: las de 1921, 1927, 1928, 1932, y especialmente las de 1936-1939, 1948 y 1967.

\section{PRIMERAS MANIFESTACIONES Y REVUELTAS CONTRA LA DECLARACIÓN BALFOUR Y EL MANDATO BRITÁNICO (1917-1936)}

En 1936 el padre de Salma les había contado a ella y a su hermano Samir, de 17 años, lo que había sucedido en Palestina hasta ese momento desde la Declaración Balfour:

La historia empezó en 1917, cuando se promulgó la Declaración Balfour, en la que el Gobierno británico prometía otorgar a los judíos una patria nacional 
en Palestina. Los palestinos se enfrentaron a dicha Declaración con denuncias y manifestaciones. Pero ni las denuncias ni las manifestaciones sirvieron de nada. Los judíos eran una minoría muy pequeña en Palestina entonces y no constituían un peligro real. Al cabo de algunos años empezó la inmigración de los judíos de todas las partes del mundo hacia Palestina. Llegaban allí por cualquier medio. Clandestinamente, por medio del soborno, ante la vista y oídos del Gobierno. Los árabes palestinos empezaron a sentir el peligro de este movimiento. Lo combatieron. Lucharon contra él. Hicieron la revolución de 1921, que el Gobierno apagó a sangre y fuego, mientras seguía adelante la avalancha de judíos hacia Palestina. En 1927 hicieron otra revolución, mayor que la de 1921. El Gobierno también la apagó a sangre y fuego. Y siguió la avalancha de judíos, que habían iniciado la compra de tierras intentando quedarse definitivamente. Una tercera revolución se alzó en 1928. Una gran revolución en la que el pueblo palestino demostró valentía y heroísmo. Pero el fin de esta revolución no fue mejor que el de las dos anteriores.

Sangre, fuego y cárceles. Y creyó el Gobierno que los árabes se habían tranquilizado, pero se vio sorprendido por una nueva revolución en 1932. Ésta también fue apagada con más sangre y más violencia y fuego. La gente empezó a desesperarse al iniciarse el año 1934. Aumentó el movimiento de adquisición de tierras a precios fantásticos por parte de los extranjeros judíos.

$\mathrm{Y}$, a pesar de todos los intentos de la prensa palestina por reavivar los sentimientos de la gente, el estado anímico de ésta había llegado a deteriorarse profundamente.

Y llegamos al año pasado, 1935, (...) cuando los palestinos descubrieron que el asunto no se reducía a meter a miles de inmigrantes judíos en Palestina y a la compra de terrenos, sino que aquello iba mas allá, hasta el contrabando de armas.

Fue cuando uno de los descargadores del muelle llevaba una caja con la inscripción "cemento". La caja se cayó y se rompió, descubriéndose así que aquel cemento era en realidad armas enviadas de contrabando desde Europa a los judíos.

Aquella caja pareció ser como una chispa que encendió de nuevo los sentimientos del pueblo. La gente empezó a comprender que aquellos intrusos no vinieron aquí sólo para amenazar sus bienes y sus tierras, sino también para amenazar sus vidas. Todo ello, a sabiendas del Gobierno de los ingleses.

La prensa se lanzó a escribir y enardecer la conciencia popular... aquella conciencia que no necesitaba más que de una cerilla para arder. Las manifestaciones recorrieron las ciudades. Se presentaron escritos de protesta al Alto Comisario británico.

Y cuando el pueblo se dio cuenta de que el Gobierno no quería escuchar su voz, comenzó el llamamiento a la huelga general (pp. 71-73).

\section{REVOLUCIÓN DE 1936-1939}

En 1936 Yúsef tenía unos 20 años, y ya lideraba la resistencia de su ciudad contra británicos y judíos. Era una especie de héroe en el Barrio de los 
Cristianos. Por eso fue a ver al padre de Salma, propietario de un restaurante, para animarle a participar en la huelga general que se estaba planeando y que incluía el cierre de todo tipo de establecimientos, como ocurrió al cabo de unos días (p. 70). Salma, entonces una chiquilla de 14 años, escuchaba a escondidas la conversación que ambos mantenían, enfadada con Yúsef por lo que le estaba pidiendo a su padre, como comenta luego ante su retrato:

Decías cosas extrañas, insólitas. ¿Por qué querías que mi padre cerrase su restaurante? ¿No sabías que ese restaurante que poseíamos es de lo que vivíamos? Es lo que pagaba la universidad de mi hermano en Beirut. Y el colegio aquí, para mí y para mi hermano. ¿Cómo viviríamos si mi padre cerrase el restaurante? Cierra tu tienda si es tu deseo. Pero deja a mi padre en paz.

Le decías: "Todos tenemos que sacrificarnos por la causa" (...)

Te oí mencionar al gobierno, los ingleses, los judíos, los árabes y Palestina (...) Te oí mencionar la palabra "armas" (...)

Por primera vez habló mi padre. Te preguntó: “¿Hablaste con George, Hanna, Mustafa?”, y siguió mencionando a todos los que poseían establecimientos y tiendas en el Barrio.

Asentiste con la cabeza.

Y volvió a preguntar: “¿Y los demás barrios?”.

Le dijiste: "El país entero cerrará dentro de unos días" (pp. 25-26).

Salma se quedó dormida, pero el estampido de las balas la despertó y, asustada, empezó a gritar. Yúsef la abrazó y la besó en la frente para tranquilizarla, y a partir de ese momento se enamoró de él (pp. 30-31). Sin embargo, era una chiquilla, y aunque tardarían casi una década en confesarse sus sentimientos y casarse, para ella él sería siempre el centro de su existencia, su primer y último amor y el símbolo de su seguridad (pp. 21-22).

Dos días antes de comenzar la huelga general, el padre de Salmà había proseguido su historia de Palestina, para que sus hijos entendieran por qué iba a participar en la huelga que se estaba preparando y por qué estaría incluso dispuesto a coger las armas si fuera necesario

Todos la hicieron suya. Hoy no sólo Jerusalén cierra sus puertas, sino también todas las ciudades de Palestina.

Samir le interrumpió:

— ¿Y hasta cuándo durará la huelga?

- Hasta que sean satisfechas nuestras peticiones de que pare la inmigración, se prohíba el contrabando de armas, y se detengan las operaciones de compra de terrenos...

— ¿Y si no se realizan estas peticiones?

—Entonces, todo a su tiempo (...). Esto parece el bramar de un río. Todo palestino siente ahora que esta batalla es su batalla definitiva contra judíos e ingleses. Si la huelga no surte efecto, entonces lo hará la revolución. Lucharemos. La sangre correrá como ríos. Resistiremos. Afrontaremos la violencia con la 
violencia. Los intrusos judíos e ingleses no entienden otra lengua. Moriremos todos si hace falta (...).

Cerraremos las tiendas, los puertos, los colegios y paralizaremos el país. Ésta es nuestra tierra, y nosotros decidiremos su futuro. Basta con que hayamos aceptado hasta ahora la colonización de los ingleses. Pero no aceptaremos de ninguna manera ser extraños en nuestra patria y la patria de nuestros antepasados. (...) Soy un hombre sencillo, un ciudadano normal. Nunca me interesé por la política. (...) En mis relaciones con la gente no distinguía entre judío, inglés $\mathrm{o}$ árabe. Tengo amigos entre los judíos y tengo amigos entre los ingleses. Pero ahora siento que éstos me amenazan personalmente. Por esto acepté participar en la huelga. Y por esto, por vosotros, estoy dispuesto a empuñar el fusil, muy a pesar mío. El asunto, hijo mío, es sencillo. Mi familia, mi vecino, todo palestino y yo, defendemos hoy nuestra tierra, nuestra dignidad y nuestro futuro... (...) -Pero los ingleses y judíos son más fuertes que vosotros, padre.

Tronó la voz de mi padre, que le contestó enojado:

- Nada es más fuerte que la verdad, hijo. Ésta es nuestra patria y es nuestra tierra. Y nadie nos la arrancará.

—ंTenéis armas para luchar? (...)

- Tenemos armas. Y compraremos armas. Sacrificaremos nuestras vidas por nuestra patria (pp. 71-76).

Mientras acababa de contar esa historia, entró Yúsef inquieto porque el Gobierno quería detenerle, junto a palestinos de las otras ciudades, por incitar a la huelga. Sus nombres aparecerían al día siguiente en los periódicos. Como había decidido no entregarse, aceptó refugiarse en casa del padre de Salma, que insistió en que se quedase con ellos a pesar del riesgo que suponía para toda su familia. Allí se trataron más Salma y Yúsef, pero él aún no parecía consciente de que ella le amaba, a pesar de que su madre, que venía a visitarle a hurtadillas, mostraba claramente su deseo de verle casarlo con Salma antes de morir.

Pero aquellos días tan felices para Salma se interrumpieron cuando el alcalde les avisó de que los soldados iban a registrar el barrio casa por casa en busca de Yúsef. Éste declinó la idea de huir disfrazado de mujer, y prefirió ir a la cárcel, pensando que su detención encendería la ira de su gente. Así se convirtió, como decían los periódicos, en "el primer preso palestino desde el inicio de la huelga" (p. 87), aunque le siguieron centenares. Salma, que le visitaba en la cárcel, no sabía que, a lo largo de su vida en común, habría de recorrerse todas las cárceles y campos de concentración de Palestina. Al cabo de dos meses le soltaron, mientras la huelga seguía como en todo su apogeo (p. 91).

Y viendo que la huelga no era suficiente, Yúsef se dedicó a incitar a usar otro lenguaje más fuerte que pudieran entender los ingleses: la lucha armada (p. 92). Las mujeres vendían sus alhajas y los hombres daban dinero para comprar armas, que ocultaban con cuidado, porque, al que le hallaban una, le llevaban a la cárcel. Y comenzó la nueva revolución, con largas ausencias de Yúsef para 
realizar todo tipo de acciones de resistencia, en las que a veces resultaba herido, como rememorará Salma tras su muerte:

Cerrasteis el puerto de Yafa para impedir que continuase la inmigración. Lanzasteis decenas de ataques contra las caravanas de los soldados ingleses. Aterrasteis al imperio en el que no se ponía el sol.

Os convertisteis en su continua preocupación.

El país permaneció en huelga. La revolución continuó ardiendo... y el número de detenidos se elevó a varios miles.

Abrieron campo de concentración para vosotros. El pueblo entero participó en la revolución. Boicoteó a los judíos. Boicoteó a los ingleses. Los periódicos cada mañana avivaban las llamas de la revolución.

Luego iniciasteis vuestros ataques contra las ciudades y colonias judías. Era suficiente que cinco de vosotros entraran en cualquier barrio judío para que todos sus vecinos huyeran como conejos.

Algunas de vuestras historias parecían mitos. $\mathrm{O}$ en realidad lo eran.

La historia de aquel camionero al que un grupo de soldados ingleses obligó a trasladarles de Jerusalén a Yafa bajo la amenaza de las armas, y que, al llegar el camión a Bab al-Wad, y mientras la pistola seguía apuntando a su cabeza, giró el volante hacia el acantilando, haciendo precipitarse al camión. (...)

Ninguna madre lloraba cuando recibía la nueva de la muerte de su hijo en combate. En vez de eso hacía albórbolas. Lo celebraba. Caminaba detrás del ataúd con la cabeza alta y el semblante orgulloso (pp. 102-102).

Cada división británica tenía 15.000 soldados, pero no podían con los palestinos. El propio Yúsef le contó al padre de Salma las palabras que el propio Henry Wilson, que entonces mandaba las tropas británicas en Palestina, había pronunciado:

No se puede vencer a quinientos revolucionarios árabes de Palestina, que se hacen fuertes en las montañas y recurren a la guerra de guerrillas, con menos de una división británica con todas sus armas (p.114).

Durante el tiempo que duró aquella revuelta, a la que se unió Samir, el hermano de Salma, Yúsef se convirtió en un mito en su barrio, en Jerusalén y en toda Palestina, mientras el gobierno le perseguía sin lograr detenerle (pp. 104, 115). Y todos se acostumbraron a los continuos e inútiles registros de la casa de Yúsef en busca de armas, que no encontraron hasta después de su muerte.

Hubo muchas detenciones, encarcelamientos y ejecuciones, que no hacían sino avivar la revuelta. Y el mundo entero, especialmente los árabes, hablaba del heroísmo de los palestinos. Un político iraquí llegó a decir que cuando visitaban Europa tras aquella revuelta se sentía orgullosos de ser árabes, algo que evitaban parecer con anterioridad (p. 115). 
Pero la revuelta acabó cuando Yúsef decidió que tenían que matar a los palestinos traidores que tratasen con el enemigo, vendiesen tierras a los judíos o actuasen como intermediarios, traidores que la Inteligencia británica aprovechaba para minar la resistencia árabe. Tras matar a muchos traidores, asesinaron a dos patriotas, lo que acabó por desviar la revolución de su objetivo. Incluso otros árabes atentaron contra Yúsef en el propio Barrio de los Cristianos. Ya nadie se fiaba de nadie, y las armas se habían vuelto contra los suyos (p.117). El padre de Salma le había advertido que aquello sólo beneficiaría a los ingleses y a los judíos, como así ocurrió...

- ¿No te dije que el asesinato político es un arma de doble filo? Aquí tienes el resultado. Habéis asesinado a la revolución (p. 119).

También colaboró a que acabase el que, hacia el final de la revuelta, se supiera que se iba crear una comisión para estudiar el futuro de Palestina. Pero el padre de Salma le comentó a Yúsef que acabarían igual que las anteriores, porque todas las comisiones inglesas, americanas o de cualquier otro país partían de una falsa premisa: consideraban que los judíos tenían derecho a Palestina (p.135).

Pero el golpe final, tras seis meses de lucha armada, lo dieron los propios líderes de los países árabes:

- (...) Cuando el Gobierno británico fracasó en poner fin a la revolución por la fuerza de las armas, presionó a los reyes y presidentes árabes, para que presionaran a su vez sobre nosotros. Y efectivamente, nos llegó un telegrama suyo hace unos días pidiendo que se detuviera la revolución. He leído el telegrama que decía así: "Sentimos un gran dolor por la situación que reina en Palestina. Así que nosotros, de acuerdo con nuestros hermanos reyes de los árabes y el príncipe Abdullah, os exhortamos a mantener la calma para impedir el derramamiento de sangre, apoyándonos en las buenas intenciones de nuestro amigo, el Gobierno Británico, y en su proclamado deseo de hacer justicia. Estad seguros de que seguiremos esforzándonos por ayudaros" (p. 140).

Acabaron dejando las armas contra su voluntad, y Yúsef siempre diría, proféticamente, que Palestina se perdió el día que pusieron fin a la revolución de 1936-1939 (p. 41).

\section{LA SEGUNDA GUERRA MUNDIAL Y LA PARTICIÓN DE PALESTINA}

El estallido de la segunda guerra mundial acabó con sus últimas esperanzas, como le dirá luego Salma a su esposo muerto:

Se proclamó la Segunda Guerra Mundial, asfixiando cualquier intento de revolución en Palestina. Y vuestra esperanza se volvió hacia Alemania, ese Estado fuerte que combatía contra los ingleses, ya que, si Alemania obtuviese la 
victoria en la guerra, moriría la esperanza de los judíos de fundar una patria nacional en Palestina.

$Y$ todas vuestras esperanzas se cifraban en esta victoria. La victoria supondría el aniquilamiento de Gran Bretaña y éste supondría el aniquilamiento del sueño de los judíos en Palestina.

Por eso rechazasteis enrolaros como voluntarios en el ejército de los ingleses cuando os lo pidieron. Vosotros no queríais combatir contra Alemania. Vuestra única esperanza era desembarazaros de la colonización británica.

Y por eso los judíos se lanzaron a enrolarse voluntariamente por centenares, hasta el punto que pusieron su nombre, el nombre de los judíos, a una división del ejército inglés.

Y mientras vosotros rezabais para que Hitler obtuviera la victoria, ellos combatían para que fuese derrotado. Se entrenaban en la guerra... robaban las armas y las escondían preparándose para la siguiente ronda contra vosotros [los árabes palestinos].

Vuestras oraciones fueron inútiles.

Y Hitler no obtuvo la victoria. Los ingleses entraron en Berlín, en vez de que la cruz gamada ondeara en Londres.

Se reavivó la esperanza de los judíos en la patria nacional (...)

Lucharon codo con codo con los ingleses. Obtuvieron la victoria con ellos.

Y toda victoria tiene su precio.

El precio que reclamaron fue Palestina (pp. 142-144).

A partir de entonces, la inmigración de los judíos procedentes del holocausto nazi se multiplicó de forma alarmante, a pesar de las protestas y manifestaciones palestinas, y el gobierno británico les donó muchas tierras en las que empezaron a construir sus colonias y pueblos bajo la protección inglesa (p. 144).

Pero lo peor llegó en 1947, cuando la Sociedad de Naciones decidió la Partición de Palestina en un Estado judío y otro árabe, algo que los árabes rechazaron porque les robaban su patria para lavar la conciencia del mundo por el holocausto nazi.

\section{GUERRA DE 1948-1949}

Cuando las tropas británicas abandonaron Palestina el 15 de mayo de 1948 y los judíos proclamaron el Estado de Israel, se desató la guerra árabe-israelí de 1948-1949 que acabó en una gran derrota de los ejércitos árabes y la pérdida de más tierras palestinas.

Yúsef, que entretanto ya se había casado con Salma, también había empuñado las armas en esa guerra, resultando herido como tantos palestinos. Pero había aprendido la lección de los asesinatos políticos, y se negó a ejecutar a ningún árabe, por traidor que fuera, pues su único enemigo era Israel. Sin embargo, la ayuda árabe acabó con la resistencia, como resumiría luego Salma: 
Luchasteis y obtuvisteis la victoria.

Intervinieron "nuestros hermanos árabes".

Dijeron exactamente igual que en 1936: "Arrojad las armas y nosotros os garantizaremos la victoria”.

Y sus ejércitos entraron en combate.

Se proclamó el primer armisticio.

Prosiguieron los enfrentamientos.

Se proclamó el segundo armisticio.

Se dividió Palestina, y los judíos tomaron de ella más del doble de lo que se determinó en el documento de las Naciones Unidas.

$\mathrm{Y}$ un millón de palestinos fueron expulsados de sus hogares para vivir en tiendas de campaña (p. 150).

En Nochebuena de 1949, Yúsef lloró ante Salma por primera vez. Subió a la azotea a contemplar la Jerusalén occidental perdida, mientras se preguntaba cómo había podido ocurrir. Sólo años más tarde le comentaría a Salma:

Cayó cuando nosotros los palestinos arrojamos las armas y aceptamos entregar a otros la responsabilidad de acabar la batalla (...)

No empuñaré un arma a partir de hoy. Viviré como cualquier otro ciudadano. Volveré a la tienda para ocuparme de ella (p. 109).

Y volvió a su tienda. Pero Salma pensaba que Yúsef se iba a derrumbar. Estaba taciturno, triste, y cuando leía noticias de otras revoluciones que ocurrían en el mundo árabe, ni se inmutaba, porque le resultaban ajenas. Sólo las noticias de actos de la guerrilla dentro de Israel le hacían sonreír. Desde entonces Salma creyó que Yúsef había abandonado definitivamente las armas, como le comentaría ante su fotografía tras su muerte:

Tú no empuñabas un arma desde el año 1948.

$\mathrm{Ni}$ tú ni ninguno de tus compañeros llevaba armas desde que se perdió la mitad de Palestina.

Estuviste a punto de suicidarte cuando te obligaron a arrojar las armas.

Estuviste a punto de suicidarte cuando se te dijo: "No habrá revolución ni guerra a partir de hoy".

Tregua, te dijeron, Yúsef.

No habrá guerra.

Todo lo que habías hecho se hizo cenizas aquel día.

Se pedieron Lidda, Ramallah, Yafa, Acre, Haifa... Y sobre mi pecho lloraste lágrimas y sangre cuando arrojaste las armas (pp. 42-43).

Pero la vida y la lucha siguieron: Yúsef continuaba llevando la gran tienda que había heredado de su padre y, a pesar de su juramento, siguió conectado con la resistencia. Y Salma lograba por fin tener a su hijo Rayá en 1958, lo que les daría nuevos ánimos y sería el mejor bálsamo para la profunda tristeza de su marido. 
A partir de ese día, Salma intentaría convencer a Yúsef de la inutilidad de proseguir la lucha:

¿Es que todavía no puedes reconocer, para tus adentros, que lo que se perdió de Palestina, perdido está?

Basta de torturarte a ti mismo.

Basta ya de conversaciones que no traen más que amargura y humillación:

"Nosotros, el pueblo de Palestina, tuvimos la victoria. Quienes perdieron fueron los árabes y los ejércitos árabes"-

¿Qué palabrería es ésta? Lo que importa es el resultado. ¿Dónde está Yafa, dónde Haifa, dónde Safad, dónde San Juan de Acre, dónde... dónde... dónde? Son hoy Israel. Pesan sobre tu pecho como la verdad.

Basta de palabras sobre los actos heroicos que organizaste y protagonizó el pueblo de Palestina. Actos heroicos de los años 1921, 1927, 1928, 1933 y luego a gran revolución del año 1936.

La heroicidad de un pueblo. La revolución de un pueblo. La lucha de un pueblo. Es lo que decías cuando las circunstancias eran favorables. Y cuando no lo son, ¿para qué sirve todo esto?

La mitad de tu pueblo vive ahora bajo las tiendas de campaña mendigando un bocado de comida.

¡Ojalá nunca hubiera luchado si éste iba a ser el resultado!

Nunca en tu vida te dejaré llevar armas. Me basta el haber aguantado tu locura el año 1936, y tu locura en el año 1948. Basta.

Ahora eres padre. Padre de un niño de un mes de edad. Por él tienes que vivir y por él tienes que luchar (...). Tu hijo tampoco llevará armas. No le enseñaré un arma en su vida (pp. 43-44).

\section{GUERRA DE JUNIO DE 1967}

Pero los primeros cañonazos y el rugir de los aviones el 5 de junio del 67 despertaron al luchador que había en Yúsef, que le dijo:

-Oye, Salma. La batalla. La batalla que esperé durante diecinueve años. Nuestra batalla. La batalla de la venganza. La batalla de la liberación de Palestina (...). Debemos reunirnos, Salma. Tenemos que ir todos nosotros, todos los jóvenes del Barrio, y pedir armas al gobierno. Debemos participar con el ejército en la batalla. Es nuestra batalla tanto como lo es suya (pp. 46-47).

Como líder del Barrio, fue a pedir armas al gobierno, pero éste no se las dio, porque no quería que participaran en la batalla. Sin embargo, Yúsef, decidido a luchar, las consiguió de algún modo. Cuando le vio al día siguiente Salma sentado en el salón y empuñado una metralleta, se asustó. Y comentaría después ante el retrato de su marido muerto:

Te dije que esta batalla era diferente de las de 1939 y 1948 . Aquellas batallas eran entre revolucionarios y gobierno, y esta batalla es entre ejército y ejército. 
Te dije que no había lugar para ti en esta batalla. (...) ¿De qué serviría tu metralleta ante los cientos de aviones que vomitaron infierno y muerte ayer por la noche? (...)

— ¿Y de qué sirve mi vida si perdemos esta batalla? (p. 48).

Esa mañana se reunieron todos con sus armas en casa de Yúsef. Estaban enardecidos, pero no sabían cómo participar. No eran soldados sino revolucionarios, como diría Salma:

Esta batalla (...) fue con cañones y aviones. No había delante de vosotros ningún enemigo a quien pudierais enfrentaros con las metralletas, fusiles y pistolas que llevabais encima (p. 49).

No hubo batalla ese día, y por la noche se separaron quedando en volver allí al día siguiente. Salmà rememorará, meses más tarde y ante el retrato de Yúsef, aquella trágica noche y la falsedad de las noticias que transmitían las emisoras árabes:

No dormimos aquella noche. El infierno se arrojaba del cielo sobre nosotros. Un ataque aéreo cada hora. Cada media hora. Cada minuto.

Nos impediste huir hacia el refugio. Te quedaste sentado en tu casa desafiando las bombas, desafiando a la muerte o dándole la bienvenida.

$\mathrm{Ni}$ en un momento dormiste. Estabas sentado al lado del aparato de radio, con tu metralleta en el regazo y los oídos pegados al receptor escuchando las noticias.

Nuestras noticias y las suyas.

Creías nuestras noticias... y no dabas crédito a las suyas.

- "Obtendremos la victoria dentro de unos días. Salma, antes del fin de semana nadarás en Yafa. Antes del fin de semana iremos a nuestras playas. Ya no irás a Beirut para ver el mar, Umm Rayá. Nuestro mar ha vuelto a nosotros, querida".

Te creí aquella noche, Yúsef. Creí a las emisoras de los árabes. No dormí. Me senté junto a ti, con Rayá durmiendo en mi regazo, esperando las noticias de la victoria. Ni siquiera a mí me asustaron las bombas. Me burlé de ellas. Me burlé de Israel. Yo misma estuve a punto aquella noche de pedirte una metralleta para participar en la victoria. Cada vez que preparada una nueva cafetera y te llenaba la taza de café, te miraba y decía: “Tu próxima taza será en Tel Aviv, amor mío".

Con el alba te dormiste una hora.

Yo no dormí. Me quedé soñando con Yafa y Haifa, y con la playa que no veía desde hacía largos años.

Durante contados minutos me quedé adormecida en mi silla. Luego desperté sobresaltada. Asustada sin motivo. Un profundo sentimiento de miedo se alborotaba en mis profundidades. 
Algo me empujaba a poner la radio. Mi mano se movió sola hacia el receptor. Lo puse.

El Cairo: Umm Kulzum cantaba: "Volveré con la fuerza de las armas".

Damasco: El himno: "Dios es Grande".

Ammán: La música de "Los árabes".

Beirut: Feiruz cantaba "El retorno".

Israel: Boletín de noticias.

Y habló el locutor.

Al minuto yo estaba gritando y voceando: “¡Yúsef, Yúsef, Yúsef... Jerusalén ha caído" (pp. 50-51).

Yúsef no podía creerse la noticia, por mucho que Salma se la repitiera. Y corrió hacia la azotea con la metralleta, seguido de sus compañeros que también la habían escuchado:

Desde la azotea vigilabais. Querías ver que la noticia era cierta desde la azotea, y no de la radio del enemigo. Os aterró que el estampido de los cañones hubiera cesado. Que el ruido de los aviones se hubiera calmado. Intentaste con tus compañeros saber la verdad pero fracasasteis. Volvisteis al salón, y pusiste la radio. Las emisoras de los árabes no emitían la noticia. Entonces, era falsa. Aún así mandaste a alguien para que se informase. Le mandaste fuera de los muros de la Ciudad Vieja. Lo mandaste sin armas.

Te sentaste con el resto de los compañeros esperando. Cada minuto que pasaba parecía una eternidad. La estupefacción se apoderó de vosotros. Imposible que caiga Jerusalén. La batalla no ha empezado aún. La batalla está iniciándose. Quizás el locutor de Israel se haya equivocado y haya hablado de la caída de la Jerusalén árabe cuando quería decir la Jerusalén israelí. Prueba de ello es que el enemigo sigue fuera de los muros. No llegó a la Jerusalén antigua. No pisó con sus pies el Barrio Cristiano (pp. 53-54).

Su compañero no volvía con noticias, y la espera se hacía insufrible. Un denso silencio reinaba entre sus nerviosas caladas a los cigarrillos y un continuo quitar y poner la radio. Enviaron de nuevo a otro a informarse, que tampoco volvió. Y al poco resonó de nuevo el zumbido de los aviones, y todos se precipitaron hacia la azotea, como recuerda Salma:

Y súbitamente, en menos de unos minutos, oí el estampido de las balas. Su estampido era cercano. Muy cercano. Las balas se disparaban desde la azotea de casa. Pero lo supe antes de subir a la azotea. De pronto se abrió la puerta de la casa y vi al primer compañero que mandaste. En su cara estaba, antes de hablar, toda la noticia. Preguntó por ti. Por todos vosotros. No le contesté. Le pregunté por lo que había visto. Sencillamente atónito, dijo: "He visto tanques frente al Hotel Nacional".

¡El Hotel Nacional! Eso está muy cerca de nosotros. Muy cerca. Eso está a unos minutos de nosotros. 
Prosiguió tu compañero: "Fuera de los muros todo el mundo ha alzado banderas blancas. Sobre todas las casas vi las banderas de la derrota".

Lloró tu amigo. Lloró como un niño pequeño. No esperó de mí más preguntas. Oyó el estampido de las balas sobre la azotea. Entonces cogió el fusil y subió a por vosotros.

Involuntariamente puse la radio. La aguja seguía indicando Israel. Una voz, como si fuera la muerte, decía: "Seguid las disposiciones del Ejército de Defensa Israelí. Permaneced en vuestras casas. Alzad banderas blancas”.

No oí más. Yo también estaba llorando.

Terminó la batalla. Termino todo (pp. 55-56).

Pero Yúsef y sus hombres habían decidido impedir la entrada de los judíos al Barrio Cristiano. Y Salma renovó sus esperanzas al escuchar los disparos que partían desde su azotea:

Vuestras balas desde la azotea no cesaban. Volvió la esperanza a mi ser. Vosotros rechazaréis a los judíos (...). Vosotros no les permitiréis que ocupen la vieja Jerusalén, la Mezquita de la Roca, el Haram, la Iglesia del Santo Sepulcro, nuestro barrio, el Barrio Cristiano (pp. 56-57).

Salma se identificaba ahora plenamente con las ideas de su marido, y ardía en deseos de participar, como los hombres, en la defensa de su barrio y de Jerusalén, que ahora amaba como nunca los había amado. Para sus adentros rezaba anhelando que Yúsef y los suyos lucharan como siempre habían hecho:

Yúsef. ¡Sé héroe como te conozco! ¡Lucha (...)! ¡Demuéstrales que tu pecho es más fuerte que sus aviones y sus cañones! ¡Demuéstrales que quien defiende su patria no es como aquel que invade la patria ajena! Ellos te conocen. Conocen el sabor de la muerte cuando les haces saborearla (p. 58).

Cuando ella y su hijo acabaron de rezar por la victoria, cesó el ruido de las balas y de los aviones, y le dijo uno de ellos bajando de la azotea:

Los judíos intentan ocupar la Jerusalén vieja por medio de paracaidistas. Los aniquilamos a todos. Cada vez que un avión lanza un grupo, los aniquilamos (p. 59).

Pero les faltaban municiones, y fueron a buscarlas, porque sabían que los judíos no tardarían en volver. La situación se repitió durante varias horas, mientras las emisoras israelíes les pedían que se rindieran, y las árabes, que resistieran (p. 61). Salma sintió miedo porque, aunque cada palestino valía por cien, como decía Yúsef, el enemigo los mandaba a centenares. La radio israelí seguía conminándoles y diciendo que a sus soldados les estaban haciendo frente en Jerusalén y que les estaban disparando por la espalda. Salma sabía que los palestinos les 
estaban desafiando de frente, no por la espalda, y pensaba que los judíos mentían y eran unos cobardes y que los palestinos les obligarían a retroceder (pp.61-62). Aunque en realidad estaban luchando solos, durante horas Salma se aferraba a la esperanza por lo que escuchaba en la radio. Y animaba a Yúsef para sus adentros insistiendo en la importancia que Jerusalén tenía para todo el mundo árabe:

Los árabes luchan en todas partes, Yúsef. Así lo dicen las emisoras de radio árabes. No estáis solos en la batalla. Todos los árabes están con vosotros en la batalla.

Estáis estrujándolos como una tenaza. No tienen salvación. Mañana nos alzaremos con la victoria. Toda Jerusalén volverá a nosotros, y toda Palestina. Iremos con Rayá a Yafa. Le enseñaremos a nadar en la playa. Rayá no crecerá con la mitad de su patria perdida (...)

¡Dispara, Yúsef! ¡Golpea! ¡Resistid hasta que ganen los árabes! ¡Rechazad al enemigo lejos de los muros de vuestra ciudad! ¡Echadle de Jerusalén! Viene a por Jerusalén. Que la historia mencione que vosotros, héroes del Barrio Cristianos... que tú Yúsef... impediste a los judíos realizar su propósito. Entrarás en la historia por la puerta grande. Tú y Saladino habéis defendido Jerusalén. Tú estás en el más noble combate de la historia de los árabes. El destino de los árabes pende de estos muros. El honor de los árabes está en estos muros (pp. 62-63).

De repente sintió que Yúsef y los suyos habían dejado de disparar, aunque continuaba el zumbido de los aviones. Su marido bajó de la azotea, sombrío e irritado. Se les habían acabado las municiones, los judíos estaban a las puertas de Jerusalén y ya no había resistencia en el exterior. Y eso significaba la rendición. Yúsef parecía haber envejecido treinta años. Y Salma se quedó paralizada.

Cuando Yúsef se dio cuenta de que era imposible proseguir la lucha, decidieron utilizar los últimos cartuchos matando a todo soldado israelí que entrase en Jerusalén y en el Barrio de los Cristianos. Cada uno marchó a su casa a apostarse tras las ventanas con el gatillo presto a disparar. Así fueron matando, con balas y granadas, a centenares de judíos. Cuando Yúsef se quedó sin balas, no se rindió, y salió a la calle a clavar la bayoneta de su fusil al último soldado que viera ese día. Y luego volvió a su casa, cerrando puertas y ventanas. Se negó a colgar la bandera blanca en su casa, como exigían los israelíes, pero Salma la colgó. Los vecinos del barrio, que estaban a la espero de lo que hiciera su líder, también la colgaron. Sin embargo, la gente siguió resistiendo, y acabaron acudiendo a casa de Yúsef. Aquello era un funeral. La humillación les mataba, y les desgarraba la rabia. A la hora del toque de queda, marcharon de nuevo a sus casas, sumisos incluso ante las amonestaciones de cualquier soldado que se topaban.

Yúsef fue incapaz de dormir. Sólo pensaba en matarse. No podía resistir aque1lo. Y reinó un silencio mortal hasta que, de repente, llamaron a la puerta con unos golpes fuertes, como luego contaría Salma: 
Me levanté a abrir al oírlos, y me sorprendió un soldado israelí que me empujó violentamente hacia dentro, irrumpiendo en la casa con su arma en la mano, seguido de un grupo de sus compañeros, mientras gritaba:

—¿¿Dónde está tu marido?... ¿Dónde está Yúsef?

Y antes de contestar se lanzó hacia el dormitorio, apoyando la boca de su pistola en tu cabeza y gritándote:

- No ofrezcas ninguna resistencia... Acompáñanos inmediatamente.

No te permitieron cambiarte de ropa, ni siquiera te dejaron echar un vistazo a tu hijo, que dormía en la habitación contigua, sino que se precipitaron a ponerte las esposas en las manos y a arrastrarte hacia la calle (p. 159).

Yúsef salió de su casa rodeado de soldados que le apuntaban con sus metralletas. Todo el vecindario se había despertado y se asomaba a ventanas y azoteas esperando verle salir y sufriendo por el destino de su héroe. Yúsef, con el rostro cadavérico, se despidió de Salma y le dijo que cuidara de Rayá y que le dijera que quería que fuera un hombre como su padre. Salma aún no sabía que ése era su testamento, pues pensaba que se lo llevarían a la cárcel por un tiempo, pero le siguió descalza como si le estuviera dando el último adiós... Y así fue, porque su compañero Adnán estaba apostado en una ventana con una bomba en la mano. Así recordará Salma el momento final:

Adnán había jurado matar al primer israelí que entrase en el Barrio Cristiano. Pero este primer israelí caminaba contigo a su lado.

¿Cómo golpearles si para cumplir su juramento tenía que causar tu propia muerte?

Pareció que te percataste de lo que rondaba por su mente.

Entonces zanjaste la situación.

Te paraste inmóvil en tu sitio y, disimuladamente, le hiciste una señal para que lanzase la granada.

No acató tu orden. Te indicó que se negaba. Entonces hiciste violentamente una señal para que la lanzase... Los soldados se dieron cuenta de tu gesto.

Alzaron sus metralletas hacia el lugar al que mirabas...

Entonces lanzó Adnán la granada.

Y perdí el sentido (pp. 161-162).

Meses más tarde aun seguía sin creerse cómo había muerto Yúsef:

Si entonces hubieses tenido el arma en tus manos, no te habrían matado.

$\mathrm{El}$ arma en tu mano era más fuerte que todos tus enemigos.

Todavía no puedo creer que te dieran muerte con el arma de tu amigo.

¿Qué tu amigo y compañero y colega te había matado?

Sean cuales fueran las circunstancias y los motivos, yo no lo creo.

A pesar de que él murió un minuto después de ti, yo no lo creo.

Se dijo que fuiste tú quien le empujó a matarte. Que le pediste que te matase cuando te viste rodeado por los soldados de Israel y desarmado (p. 95). 
Pero más tarde reconocería que en su fuero interno intuyó, al verle salir esposado ese 8 de junio, que nunca volvería a casa, que era su último viaje:

Sabía que no ibas a volver.

Que no soportarías que Jerusalén estuviese bajo la ocupación.

Que tus nervios te iban a traicionar.

Que morirías al ver a un israelí besar a una israelí en la Mezquita de al-Aqsa o sobre el Santo Sepulcro de Jesucristo.

Y no volviste (pp. 104-105).

Era el final de la batalla que Israel había lanzado el 5 de junio de 1967. Había sido un rápido ataque sorpresa contra los países árabes vecinos y su tierra, y en seis días habían ocupado lo que quedaba de Palestina, incluida Jerusalén oriental. Este golpe causó un enorme trauma en todo el mundo árabe, y parecía presagiar la rendición y el final de la causa palestina, como nos recordaba Nabil Juri en el prólogo.

\section{DESESPERACIÓN TRAS LA MUERTE DE YÚSEF Y LA OCUPACIÓN}

El relato de todos estos hechos lo comienza Salma muchos meses después de esta tragedia, cuando va desgranando con nostalgia toda su historia ante la fotografía de su marido ya muerto.

Veía sonreír a las viudas de otros caídos, pero ella no podía sino llorar su inmenso drama, del que ni siquiera en Dios hallaba consuelo. La muerte de Yúsef también suponía el final para su vida: se sentía sola y desamparada, pues había perdido a su gran amor y a su gran protector, al que creía inmortal porque siempre sobrevivía a todas las batallas de la resistencia en las que participaba. Y cada vez que se ausentaba le decía: "No temas, Salma. Siempre volveré”... (p. 101).

En unos cuantos párrafos Salma resume con amargura la larga lucha de Yúsef contra los judíos, preguntándose de qué había servido:

Vivió y murió resistiendo.

¿Fue útil su resistencia? ¿Fue provechosa su lucha? ¿Triunfó su combate? ¿No cayó la ciudad que amaba? ¿No la ocuparon aquellos a quienes había combatido toda su vida? ¿No entraron en su casa y se burlaron de la fotografía en que aparecía empuñando su metralleta? ¿No humillaron a su mujer? ¿No ofendieron a su madre?

¿Acaso había combatido, guerreado, resistido y luchado por esto?

$¿ \mathrm{O}$ es que el destino de la ciudad que amaba estaba ligado a su vida, y cuando aquélla cayó, cayó ésta?

¡Jerusalén —le decía a ella—, Jerusalén! ¡No hay vida sin Jerusalén, la amada de los árabes! Y si se pierde, los árabes se perderán.

¡Se perdió Jerusalén, Yúsef!

¿La viste caer? 
No, tus nervios no resistieron lo sucedido. Deseaste la muerte. La pediste, pediste a tu amigo, al compañero de adolescencia y colega de la niñez, que te matara.

¡Cuarenta años, Yúsef!

¡Cuarenta años estuviste combatiendo para que no se perdiera Jerusalén, para que no se perdiera el Barrio, tu barrio, para que no cayera!

Y cayó. Como un sueño, en cuarenta horas (pp. 14-15).

Al caer Jerusalén, la ciudad que tanto amaba, también había caído Yúsef:

Te has muerto... Te has ido. No estás aquí. No volverás. La tierra del Barrio absorbió tu sangre cuando tu cuerpo fue destrozado por la bomba (p. 91).

Cuando caíste muerto, no había arma alguna en tus manos, porque no estabas en una batalla.

La batalla había acabado y Jerusalén había caído. Y había caído el Barrio Cristianos. Y la Patria entera.

Tal vez éste haya sido el motivo de tu muerte (p. 95).

Salma está enojada con Yúsef por haberla dejado sola. Ahora se siente indefensa ante las humillaciones a las que la someten los vencedores, como había ocurrido un día que los judíos registraban la casa del difunto en busca de armas:

¿Dónde estás para repeler la mano que me agarró bajo la amenaza del revolver? A mí no me había tocado nadie más que tú...

¿Cómo me ha tocado ese asqueroso?

¿Dónde estás para defenderme?

¿No pensaste en mí mientras buscabas la muerte?

¿No sabías que quien ocupó la ciudad y el Barrio intentaría ocupar tu casa y poner su mano donde la tuya? (p. 16).

Ante la pérdida de su amado Yúsef, ya ni siquiera le importa la ocupación de Jerusalén:

¡Caiga mil veces Jerusalén y quedes tú! Tú eres mi Jerusalén. Las piedras negras de la ciudad no me importan. Los adoquines lisos del Barrio me dan igual (p.16).

Tampoco le importa que todos le consideren un héroe:

Toda la gente de Jerusalén dice que no has muerto. Que estás vivo y que eres un mártir, que eres un héroe, $\mathrm{y}$ los héroes no mueren.

¡Ah!... ¡ $\mathrm{Si}$ supieran que toda tu heroicidad no me compensaría del tacto de la palma de tu mano ahora! (...)

Te entregaba mi ser, como tiene que ser la entrega, a un héroe, no a un hombre corriente. 
¿Pero de qué nos ha servido tu heroicidad?

Los cobardes duermen ahora al lado de sus esposas y niños.

¡Ojalá hubieras sido un cobarde!

¡Ojalá no hubieras amado a Jerusalén!

¡Ojalá no hubieras amado al Barrio Cristiano! (...)

Los miles que murieron por Palestina desde hace medio siglo no tenían que haber muerto.

Gratuitamente perdieron sus vidas. Su sangre fue derramada en vano.

Los que pagamos el precio somos nosotras, viudas, y nuestros niños huérfanos.

Ayer vendí tu tienda, Yúsef, para vivir, para dar de comer a tu hijo.

Mañana venderé la casa.

Otras de las mujeres de tus compañeros vendieron algo que es mucho más caro que esto.

Todo lo que dijiste sobre la tierra, la patria, el sacrificio patriótico y la abnegación, es pura palabrería, Yúsef.

Un pelo tuyo vale por todas las patrias del mundo (pp. 35-37).

Salma se siente tan muerta como lo está Yúsef:

¡Ambos estamos muertos... Yúsef!

Tú estás muerto allá donde estás, y yo estoy muerta donde me dejaste... (...)

Pero yo no tengo certificado de defunción... Y ahora que me acuerdo... Tú tampoco tienes certificado de defunción.

Tú, para el nuevo Estado, no has muero. El médico que suele firmar estos certificados murió una hora antes que tú.

Los judíos le dispararon por la espalda cuando intentaba prestar auxilio a un herido en la calle.

Cuando la gente muere por decenas y por centenares, nadie pregunta por el certificado de defunción (pp. 19-20).

Ahora, su único motivo para seguir viviendo es Rayá. Y cuando éste le pregunta por su padre, ella le oculta la verdad y le dice que está de viaje y que volverá por Nochebuena, para comprarle juguetes y adornarle el árbol de Navidad (p. 13).

A pesar de todo, se siente orgullosa de su marido, pues hasta los judíos reconocían su valentía y le temían, como le había dicho uno de ellos al ir a su casa a hacer el censo para el nuevo gobierno israelí:

- ¿Su nombre?

-Salma...

- ¿Salma qué?

—Salma Ráshed...

- ¿Vive sola aquí?

—Sí, con mi niño...

— ¿Y su marido? 
-Murió...

—¿Cuándo?

—En la última guerra.

- ¡Ah!... ¿Qué día?

- ¿Por qué quiere saber qué día? ¿No basta con que sepa que ha muerto?

- Instrucciones, Madame. Instrucciones del gobierno.

— ¡Váyanse usted y su gobierno al infierno!

-No. No hable así, Madame. Nosotros aquí la ayudamos.

- No queremos su ayuda, queremos que se marchen.

— ¡Já! ¡Já!. ¡Llevamos dos mil años soñando con Yerushalayim y después de haberla tomado nos vamos a marchar...! ¡Já!... ¡Já!...

- Le ruego que escriba los datos y se vaya.

-Tiene que ayudarme.

—¿Qué quiere?

—¿Qué día murió su marido?

-El ocho de junio.

- ¿Cómo se llamaba?

- Se llamaba Yúsef. Yúsef Ráshed.

- ¡Ah! Conocía a su marido.

- ¿Conocía a mi marido! Pues mi marido no les conocía a ninguno de ustedes.

-Quiero decir que oía hablar de él. Nosotros los judíos temíamos su nombre en el 36 y en el 48. Su marido era valiente, Madame, y yo respeto a los valientes. Tome, ésta es una hoja de censo del gobierno de Israel.

-No quiero ningún papel del gobierno de Israel. Lo romperé.

-Es usted libre (pp. 37-39).

En efecto, los judíos no se iban a marchar. Habían logrado su objetivo, pero por encima del cadáver de Yúsef. Jerusalén ahora estaba bajo la férula de los israelíes, y todos los palestinos los odiaban, entre ellos su hijo Rayá, que ahora tenía 12 años, como le cuenta Salma a su marido muerto:

Los colegios no abrieron hasta ayer, Yúsef. Estaban en huelga. Les obligaron a abrir. Tu hijo no quiere ir al colegio. Es testarudo como tú. Él siente que algo ha cambiado en Jerusalén. En el Barrio. Ve a los soldados que llenan las calles, soldados extraños. De lengua extraña para sus oídos. Ayer me dijo que les odia. No quiere verles. Su odio es espontáneo, instintivo (p.39).

Y le sigue contando que Rayá les desafía con la mirada y la defiende cuando los judíos van a registrar su casa en busca de armas, cuya existencia ignoraba Salma, e intentan llevársela presa:

- ¿Qué quiere? No hay hombres en casa.

- Sé que no hay hombres, pero tenemos que registrar la casa.

- ¿Registrar la casa?

-Sín... 
- ¿Buscando qué?

— Já! ¿No sabes buscando qué? Buscando armas.

-No hay armas aquí.

-Miente. Mejor que se ahorre a usted y a nosotros el sufrimiento, y nos indique el lugar de las armas.

-Le dije que no hay armas aquí.

— ¿La casa de Yúsef Ráshed, y no hay armas aquí? ¡Já!

El oficial israelí me empujó a un lado y entró. Y en cuestión de minutos toda la casa se había puesto patas arriba. Ellos registraban, y yo les gritaba que parasen, que no había armas aquí...

Pero encontraron armas, Yúsef.

Yúsef, te juro que yo no sabía que en casa había armas.

Tu metralleta desapareció el día que te mataron. Estaba contigo cuando saliste, y no volviste más que como un cadáver inerte. Y no volvió contigo.

¿De dónde son todas estas armas que encontraron en el jardín?

Yo nunca te vi, desde que nos casamos, introducirlas en casa. No me dijiste nada de ellas.

Cuando aseguré al oficial y a los soldados que no existían armas en casa no estaba mintiendo. Pero a sus ojos yo era una mentirosa. Y quisieron llevarme. Estuvieron a punto de conducirme delante de ellos a la cárcel, Yúsef. Y si no hubiera sido por la intervención de algunos "prudentes" vecinos del Barrio, esos "prudentes" que hicieron amistad con el ejército de ocupación, ahora estaría hablándote desde la cárcel, amor mío.

Tu hijo no se asustó de los soldados. Es extraño este niño. Se puso de pie agarrándome la mano y mirándoles con extraño desafío, mientras registraban la casa. (...) Sentí súbitamente que se convertía en un hombre, y que me protegerá de cualquier agresión.

Es una imagen de ti, Yúsef (40-41).

Tras conquistar toda Palestina, y ya libres de los británicos, los judíos se tomaron la revancha, como le cuenta Salma:

Muchas cosas pasaron desde que te marchaste... Los judíos anexionaron la Antigua Jerusalén, tu Jerusalén... a la Jerusalén Nueva.

Los judíos volvieron al Muro de las Lamentaciones.

Los judíos expulsaron a los palestinos del Barrio de los Magrebíes.

Los judíos ocuparon amplias extensiones de las tierras árabes en Jerusalén, para levantar sobre ellas sus propias casas.

Los judíos profanaron la Mezquita de al-Aqsa y la Iglesia del Santo Sepulcro.

Los judíos volaron decenas de nuestras casas.

Expulsaron a miles de nuestros hermanos.

Encarcelaron y torturaron a centenares de nuestros jóvenes.

Desafiaron todas las resoluciones del mundo que les pedían retirarse.

Se burlaron de toda ley y toda norma.

Robaron... Saquearon... Fueron demasiado lejos en su desafío.

Nos trataron como victoriosos. 
Superaron con creces el trato de los nazis del que suelen quejarse.

¡Qué pequeño quedó el yugo a que les sometió Hitler comparado con el yugo al que nos someten ahora!

¡Qué pequeña quedó su brutalidad al lado de la de ellos! (pp. 162-163).

El día anterior a la Nochebuena de 1967, y en otra larga parrafada, le describe a su amado otros detalles de la situación de Jerusalén Oriental y de toda Palestina bajo la ocupación israelí, marcando el contraste entre el antes y el después, entre la alegría de los judíos y la tristeza de los árabes:

Jerusalén, después de tu marcha, se oscureció. Se convirtió en una ciudad de fantasmas.

Cada día un israelí besa a una israelí en la Mezquita de al-Aqsa y en la Iglesia del Santo Sepulcro. Se retratan allí. Alzan su bandera allí. Nos desafían. Desafían nuestros sentimientos. Nos desprecian. Nos tratan con la mentalidad del vencedor.

Yo no se lo reprocho. Obtuvieron la victoria, oh, Yúsef. Te mataron. Mataron a tus hermanos. Deportaron a tu pueblo. Ocuparon toda tu patria. Cada palmo de tu patria está a su merced. Nosotros estamos a su merced. Yo lo estoy. Y tu hijo.

El más insignificante de sus soldados nos escupe a la cara si quiere. Nos encierran detrás de las puertas de nuestras casas como si fuéramos conejos. Nos cortan el agua. Los alimentos. La luz.

Nos permiten movernos libremente un día, y nos lo prohíben a lo largo de varios días.

Si quisiera salir de Jerusalén tendría que esperar de pie a la puerta del gobernador militar israelí varias horas, junto con centenares de personas.

Quizás lo aceptase. Quizás lo denegase.

Quizás me echase.

No podría protestar. No podría oponerme. Se guardián me pegaría. Me daría patadas. Me escupiría a la cara. Me arrojaría a la calle.

¿Acaso no soy una mujer del pueblo derrotado? ¿Acaso no soy una del pueblo que perdió su patria en unas horas, del pueblo que combatió, luchó y se alzó en armas a lo largo de cincuenta años, y luego fue aniquilado en cinco horas? (...) Tú combatiste en una batalla, perdiste y moriste.

No saboreaste la amargura de la derrota.

El fantasma de la ocupación no se sentó sobre tu pecho más que por unas horas.

Este fantasma está asentado sobre nuestros pechos desde hace meses. Nos está ahogando. Ahoga nuestra respiración.

Ayer era sábado. El día de su descanso. Su día festivo. Cientos de ellos vinieron aquí. A Jerusalén. Vinieron a visitar el Muro de las Lamentaciones. Pero no lloraron. No vertieron ni una sola lágrima. Desde hace cientos de años lloran al visitar el Muro, pero hoy, habiéndose apoderado ya de Jerusalén, ¿para qué van a llorar?

Se casan junto al Muro. Descorchan botellas de champagne, bailan y cantan. 
Y nosotros... lloramos.

Buscamos un Muro de Lamentaciones para llorar junto a él la patria perdida, el orgullo perdido, la historia perdida.

Mañana será el día de Nochebuena.

Desde que tengo uso de razón, la Nochebuena en Jerusalén y Belén fue siempre la noche más bonita.

Hoy es la noche más oscura... ¡Oh, Yúsef!

En toda la ciudad no se alzó un solo árbol de Navidad. No se adornó una sola casa. No se adornó un solo escaparate.

Las campanas de las iglesias doblan con tristes campanadas. La gente no reza. La gente se esconde en sus casas. Se esconden mientras abrazan a sus hijos y les cuentan historias sobre la patria perdida y las tristes fiestas (pp. 105-107).

\section{Y RENACE LA ESPERANZA}

Hacia el final de la novela, Salma recobra la sonrisa y la esperanza al escuchar de nuevo las balas de lo fedayines, que ya se han dado cuenta de que sólo ellos podrían resolver la cuestión palestina, mediante la lucha armada, y le comenta a su amado:

Pero sucedió otra cosa, Yúsef... Sucedió lo que siempre deseabas que sucediese. Tu pueblo se despertó...

El pueblo de Palestina...

Se despertó de su sueño...

De la pesadilla que le había oprimido el pecho a lo largo de veinte años.

Tu pueblo volvió a empuñar las armas.

Volvió, volvió a la lucha ahora que Israel ocupaba toda su patria.

Volvió a la lucha que tú iniciaste hace ahora treinta años... (...)

Nuestras bombas les atemorizan porque tenemos razón.

Nosotros queremos nuestra patria.

Somos el pueblo de Palestina, y liberaremos Palestina.

Esta vez nadie nos detendrá.

Nadie nos ordenará... un armisticio.

Esta vez lucharemos hasta recuperar nuestra Patria perdida... Toda (pp. 163-164).

Salma vuelve a colgar la foto de Yúsef en el sitio principal del salón tras quitarle la banda de luto que la rodeaba. Siente que su marido vuelve a la vida en cada fedayín que combate a Israel. Le cuenta a su hijo la verdad sobre su padre, y éste camina orgulloso entre sus compañeros, porque es el hijo del héroe. Y desea, como su madre, crecer pronto para unirse a la caravana de los héroes (pp. 165-166).

Yúsef... La batalla volvió a donde tú quisiste que volviera. Vuestras balas volvieron a hacer albórbolas en el pecho del enemigo. La causa vuelve a sus dueños. Fuiste el primer mártir de la nueva batalla. 
Cuando tu sangre regó la tierra del Barrio Cristiano creí que se había derramado en balde. Que la causa había acabado. Que te habías muerto como antes murieron otros inútilmente.

Pero no, tu historia, tu martirio, no fueron en balde.

$\mathrm{Al}$ revés, fue un acicate. Fue un motivo que impulsaba a iniciar una nueva batalla. Una batalla que no acabará más que con el aniquilamiento de todos tus compañeros... o la victoria (p. 152).

Nombre del autor: Clara $\mathrm{M}^{\mathrm{a}}$ Thomas de Antonio

Dirección-e: $\quad$ cthomas@us.es

Dirección postal: Universidad de Sevilla, Dpto. de Filologías Integradas, Facultad de Filología, C/ Palos de la Frontera, s/n, 41004, Sevilla

Fecha de recepción: 15/04/2010

Fechade aceptación: 15/04/2010 